\title{
Role of Specific Synaptic Plasticity Interfering Peptides in the Expression of Morphine Induced Conditioned Place Preference in Mice
}

\author{
WU Kun ${ }^{1,2}$, XU Lin ${ }^{1}$, HUANG Jing-fei ${ }^{3, *}$ \\ ( 1. Key Laboratory of Animal Models and Human Disease Mechanisms, the Chinese Academy of Sciences \& Yunnan Province, Kunming Institute of \\ Zoology, Kunming 650223, China; 2. Graduate School of the Chinese Academy of Sciences, Bejiing 100049, China;3. State Key Laboratory of \\ Genetic Resources and Evolution, Kunming Institute of Zoology , the Chinese Academy of Sciences, Kunming 650223, China)
}

\begin{abstract}
Learned association between context and drug abuse is essential for the drug conditioned place preference (CPP), which is an animal model widely used to measure drug reward. Synaptic plasticity, in the form of long-term potentiation (LTP) and depression (LTD), is regarded as a proposed cellular substrate of learning and memory. However, the exact role of LTP/LTD in addiction is not known yet. Therefore, by bioinformatics we designed peptides aiming to interfere with LTP and LTD respectively, to study their individual role in the expression of morphine CPP. We found that the interfering peptide Pep-A2 can specifically block hippocampal LTP in CA1 region, whereas Pep-A3 can block LTD in this region. Treatment of either of their cell penetrating forms (Tat-A2 or Tat-A3) before test can block the expression of Morphine CPP in mice. These results suggested that both LTP and LTD are required in the drug-associated learning and memory.
\end{abstract}

Key words: LTP; LTD; Reward; CPP

\section{特异突触可塑性干扰肽在小鼠吗啡条件化位置偏爱表达过程中的作用}

\author{
吴 坤 ${ }^{1,2}$, 徐 林 $^{1}$, 黄京飞 ${ }^{3, *}$ \\ (1. 中国科学院昆明动物研究所 中国科学院\&云南省动物模型与人类疾病机理重点实验室, 云南 昆明 $650223 ; 2$. 中国科学院研究生院, \\ 北京 100049 ; 3. 中国科学院昆明动物研究所 遗传资源与进化国家重点实验室, 云南 昆明 650223)
}

摘要: 在作为成瘾检测手段的条件化位置偏爱模型中, 环境背景和成瘾药物间的关联性学习起着关键的作用。 突触可塑性作为学习记忆可能的物质基础, 在药物成瘾方面的研究也越来越多, 但其表现形式, 长时程增强(LTP) 或者长时程抑制(LTD)在成瘾过程中所发挥的具体作用尚不得而知。因此, 本文利用生物信息学手段, 设计并合成 了旨在分别阻断 LTP 和 LTD 的干扰肽, 研究其对小鼠吗啡条件化位置偏爱的影响。结果发现, 干扰肽 Pep-A2 和 Pep-A3 能够分别特异地阻断海马 CA1 区的 LTP 和 LTD, 在测试前尾静脉注射具有穿膜特性的 LTP/LTD 特异性干 扰肽 (Tat-A2/Tat-A3), 均能阻断或损伤吗啡诱导的条件化位置偏爱的表达。此发现提示我们, LTP 和 LTD 在成 瘾性异常记忆的过程中均发挥着重要的作用。

关键词: 长时程增强; 长时程抑制; 奖赏; 条件化位置偏爱

中图分类号: Q42; R338; Q959.837 文献标识码：A 文章编号：0254-5853-(2009)04-0389-07

The conditioned place preference (CPP) paradigm is exemplar of classical pavlovian conditioning which involves associative learning and memory processes (White \& Carr, 1985). CPP has been successfully used to evaluate the rewarding effects of drugs (Tzschentke,
1998). The expression of CPP on a drug-free state may require memory for the association between environmental cues and the affective state produced by the treatment (Hsu et al, 2002).

Previous studies have shown that the mechanisms

Received date: 2009-05-13; Accepted date: 2009-06-09

收稿日期：2009-05-13；接受日期：2009-06-09

基金项目： This work was supported by the National Natural Science Foundation of China(30530250; 30623007)

*通讯作者 (Corresponding author), E-mail: huangjf@mail.kiz.ac.cn 
underlying acquisition and expression of opiate CPP differ substantially (Timothy, 1989), and suggested that the expression of morphine reward is probably independent on opiate or catecholamine activity, and rather attributes to as yet unknown mechanisms.

Synaptic plasticity, including hippocampal LTP and LTD, as a proposed substrate of learning and memory (Kauer, 2004; Malenka, 2003; Malinow \& Malenka, 2002), has been demonstrated in neural reward circuits and might contribute to the learning of addictive behaviours (Jones \& Bonci, 2004). However, we still know little about their exact roles in this type of drug-associated learning and memory.

$\alpha$-amino-3-hydroxy-5-methylisoxazole-4-propioni c acid (AMPA) receptors, as the major receptors to mediate synaptic transmission of excitatory glutamatergic synapses, are necessary for the expression of LTP and LTD. Recent studies have demonstrated that AMPA receptors are continuously recycled between intracellular compartments and the plasma membrane via vesicle-mediated plasma membrane insertion (exocytosis) and internalization (endocytosis) (Malinow \& Malenka, 2002; Bredt \& Nicoll, 2003; Collingridge et al, 2004). Therefore, synaptic plasticity could be altered by regulation of either receptor insertion or internalization.

In the present study, peptides targeted on the sequence related to AMPA receptors trafficking have been designed by bioinformatics to block LTP/LTD. The cell penetrating forms of these peptides were used to further our understanding of the individual role of LTP/LTD in the expression of CPP induced by morphine reward.

\section{Materials and Methods}

\subsection{Animals}

Experiments were performed on male Kunming mice (Animal House Center, Kunming Medical College, PR China), which were group housed under a $12 / 12 \mathrm{~h}$ light/dark cycle and temperature controlled environment $\left(22-24^{\circ} \mathrm{C}\right)$ with food and water available ad libitum. Animal care and experimental protocols were approved by the Chinese Academy of Sciences, PR China.

\subsection{Slice preparation}

The experimental protocols were approved by the Department of Biology of the Chinese Academy of Sciences, PR China. The slice preparation and electrophysiological protocols were similar to those described previously (Wu, 1998; Li, 2005). Kunming mice of $18-28$ day old were decapitated and the brain was quickly removed and immersed in ice-cold artificial cerebral spinal fluid (ACSF) in vibroslicer chamber. Hippocampal slices $(300 \mu \mathrm{m}$ thick) were cut coronally and then transferred into a submersion type incubation chamber containing $300 \mathrm{~mL}$ ACSF heated to $(30 \pm 2)^{\circ} \mathrm{C}$ for $30-60 \mathrm{~min}$ recovery. During incubation, slices were placed on nylon mesh and both sides of the slices were perfused by oxygenated ACSF. The ACSF contained (in mmol/L): $\mathrm{NaCl} 120, \mathrm{KCl} 2.5, \mathrm{NaHCO}_{3} 26$, $\mathrm{KH}_{2} \mathrm{PO}_{4} 1.25, \mathrm{CaCl}_{2} 2, \mathrm{MgSO}_{4}$ 2, D-glucose 15, pH 7.3, saturated with $95 \% \mathrm{O}_{2}$ and $5 \% \mathrm{CO}_{2}$. Then, the slice was gently transferred into a recording chamber, and held submerged between two nylon nets and maintained at room temperature $\left(22-25^{\circ} \mathrm{C}\right)$. The recording chamber consisted of a circular well of low volume $(1-2 \mathrm{~mL})$ and was perfused with ACSF at a flow rate of $3-4 \mathrm{~mL} / \mathrm{min}$. A buffer groove enchased with platinum wires was located between recording chamber and vacuum pipette to allow for the most rapid flow while minimizing cell movement.

\subsection{Eletrophysiology}

Blind whole-cell recording was obtained by using electrode $(3-6 \mathrm{M} \Omega$ ) containing (in $\mathrm{mmol} / \mathrm{L}$ ): potassium gluconate $130, \mathrm{KCl} 10, \mathrm{CaCl}_{2} 1, \mathrm{NaCl} 6$, HEPES 20, EGTA 10, Mg-ATP 3, Na-GTP 0.5, and QX-314 5, pH 7.2 , or intracellular solution supplemented with peptide $(100 \mu \mathrm{g} / \mathrm{mL}$, which was dissolved in the intracellular solution at a concentration of $5 \mathrm{mg} / \mathrm{mL}$ for stock, GL Biochem (Shanghai) Ltd. China). The membrane potential was held at $-70 \mathrm{mV}$. Electrical stimuli $(0.1 \mathrm{~ms}$ in duration) were delivered at a frequency of $0.033 \mathrm{~Hz}$ to obtain baseline $(10 \mathrm{~min})$ that were approximately half-maximal response. The same extracellular electrodes were also used for applying theta burst stimulation (TBS) to induce LTP (Ge et al, 2006). The TBS consists of a train of five bursts of stimuli at $5 \mathrm{~Hz}$ with each burst composed of five pulses $(100 \mu \mathrm{s})$ at $100 \mathrm{~Hz}$, with the same intensity as the test stimulus for evoking EPSCs, depolarizing the postsynaptic neuron to $-20 \mathrm{mV}$. The train was repeated twice with a 20 s interval. LTD was induced by low-frequency stimulation (LFS; 900 pulses, $1 \mathrm{~Hz}$ ) with the same stimulation intensity used for baseline recordings combined with depolarizing the postsynaptic neuron to $-50 \mathrm{mV}$. The whole-cell recordings were made in the presence of $100 \mu \mathrm{mol} / \mathrm{L}$ picrotoxin to block the GABAA receptor-mediated currents. For most experiments, drugs (unless otherwise noted, Sigma, St. Louis, MO) were added directly to the ACSF. 
The recording duration for the conditioning is about $40-60 \mathrm{~min}$. Series and input resistance were monitored throughout each experiment by injecting a test pulse (10 $\mathrm{ms}$ ) through recording pipettes prior to each stimulation and cells were excluded from data analysis if a greater than $20 \%$ change in the series or input resistance occurred during the course of the experiment. The LTP/LTD interfering peptides were designed by the authors using bioinformatics methods based on the underlying mechanisms targeted at $\alpha$-amino-3-hydroxy5-methylisoxazole-4-propionic acid (AMPA) receptors. Sequences of those peptides were not disclosed due to the patent.

\subsection{Behavioral test}

The conditioned place preference (CPP) apparatus consisted of two compartments $\left(201 \times 20 \mathrm{w} \times 20 \mathrm{~h} \mathrm{~cm}^{3}\right)$ with different patterns on floors and walls, which was separated by a neutral area $\left(201 \times 8 \mathrm{w} \times 20 \mathrm{~h} \mathrm{~cm}^{3}\right)$. One compartment had a plastic smooth floor and was striped horizontally with alternating $1.5 \mathrm{~cm}$ black and white tape on the wall, and the other one had a plastic mesh floor and was striped vertically. The neutral area had a punched plastic floor. Vertically and horizontally striped partition could be inserted to restrict the animals to any designated compartment if necessary. Preconditioning phase (pretest on Day 1 for $20 \mathrm{~min}$ ) was as follows: mice (weighing approximately $30 \mathrm{~g}$ ) were placed in the central neutral area and allowed to explore both compartments. Any animal that spent $>65 \%$ of their time in a large compartment or $>45 \%$ of their time in the neutral area were discarded from the study before assigning sides, due to the confounding factor of an endogenous preference or aversion. Mice were randomly assigned to four experimental groups. During the conditioning phase (Day 2-5), mice were confined to one compartment for $30 \mathrm{~min}$ immediately after injection of morphine (10 $\mathrm{mg} / \mathrm{kg}$ based on the previously described (Hnasko et al, 2005), sc, Shenyang Pharmaceutical, Shenyang, China) and to the other compartment for $30 \mathrm{~min}$ after saline injection $(1 \mathrm{~mL} / \mathrm{kg}, \mathrm{sc})$ daily, and the interval of morphine and saline injection was at $5-6 \mathrm{~h}$. CPP was tested on the following day (test, Day 6, 20min) as the protocol described in the preconditioning phase.

Data represent the percent of time spent on the drug-paired side compared to the saline-paired side before and after conditioning (that is, the ratio does not include time spent in the neutral area). Animals received either the peptide Tat-A2 $(1.5 \mathrm{nmol} / \mathrm{L} / \mathrm{g}$, iv, $n=22)$, Tat-A3 (1.5 nmol/L/g, iv, $n=19)$, Tat-Scramble $(1.5$ $\mathrm{nmol} / \mathrm{L} / \mathrm{g}$, iv, $n=19$ ) or saline (iv, $n=21$ ), $90 \mathrm{~min}$ prior to test. After peptide pretreatment all mice were returned to their homecages for $30 \mathrm{~min}$ prior to being placed in the CPP compartments.

\subsection{Data analysis and Statistics}

ANOVAs and post-hoc tests (Scheffe for electrophysiology studies and Fisher's LSD for behavioral studies) were used to analyze differences in different treatment groups. The critical value for statistical significance was set at $P<0.05$. Data are presented as mean $\pm S E M$.

\section{Results}

\subsection{Effect of peptides on hippocampal long term potentiation (LTP)}

To elucidate the individual role of LTP and LTD in the expression of morphine induced conditioned place preference, we synthesized several kinds of peptides, Pep-A2 and Pep-A3, to selectively block the LTP and LTD, with Pep-Scramble as a control. We investigated the effect of these peptides using whole-cell recordings from CA1 pyramidal neurons in acute hippocampal slices. In control slices, that without peptide in the recording pipette, an $N$-methyl-D-aspartate (NMDA) receptor dependent LTP inducing protocol (Ge et al, 2006), theta burst stimulation (TBS), yielded robust stable LTP $(P<0.01$ baseline versus $30 \mathrm{~min}$ post-induction; Fig. 1A,D). However, postsynaptic application of Pep-A2, but not Pep-A3 and Pep-Scramble, blocked the LTP (Fig. 1B-D).

\subsection{Effect of peptides on hippocampal long term depression (LTD)}

We next directly tested whether these peptides are involved in hippocampal NMDA receptor dependent LTD. After a stable baseline recording, LTD was absent in Pep-A3 (Fig. 2A, B)group by means of a low-frequency stimulation protocol which robustly triggers NMDA receptor dependent LTD, whereas in the slices from control, Pep-Scramble and Pep-A2 group (Fig. 2B, data of the last two groups were not shown because of limited numbers). LTD was readily induced by the same protocol. Thus, we conclude that intracellular application of Pep-A2 could specifically interfere with LTP, but not LTD, and the application of Pep-A3 could specifically affect LTD, but not LTP.

\subsection{The absent of LTP and LTD impair the expre- ssion of morphine induced conditioned place preference \\ To test the role of synaptic plasticity in the}


expression of Morphine CPP, the peptides Pep-A2, Pep-A3 and Pep-Scramble were fused to the membrane transduction domain of HIV-1 Tat protein to generate Tat-A2, Tat-A3 and Tat-Scramble to facilitate their intracellular delivery. Systemically treated the animals with the Tat-peptides $90 \mathrm{~min}$ before the test phase of the CPP paradigm (Fig. 3A), we found that the different types of peptides did not affect the changing weight and locomotor activity among groups of morphine conditioning mice (Fig. 3B,C). However, the expression of Morphine CPP were impaired either by the pretreatment of Tat-A2 (Fig. 3D, LTP blocked group, $P<0.05$ compared with the scramble control), or the pretreatment of Tat-A3 (Fig. 3D, LTD blocked group, $P<0.01$ compared with the scramble control, $P<0.05$ compared with the saline control). Thus, either LTP or
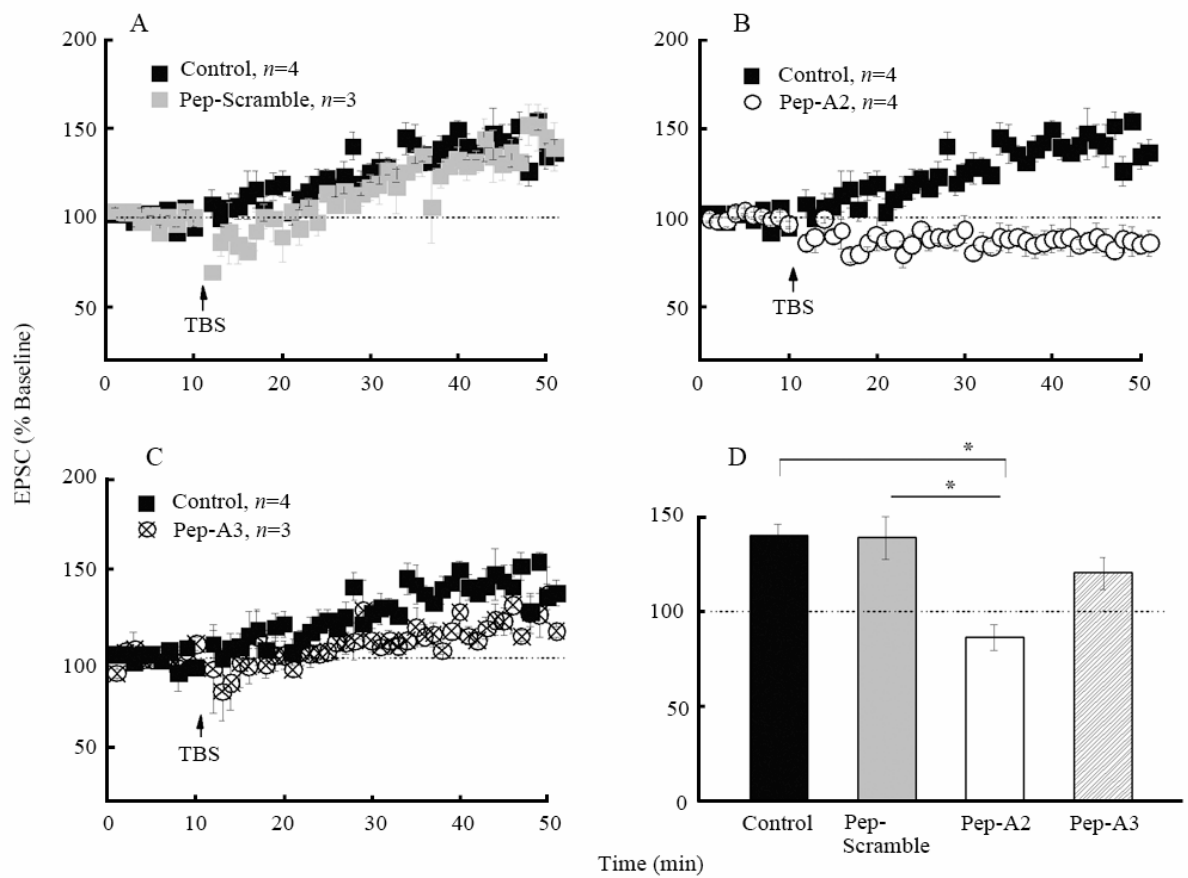

Fig. 1 Blockade of hippocampal LTP by Pep-A2 in mice

LTP was induced by pairing presynaptic stimulation TBS with postsynaptic depolarization by holding membrane potential at $-20 \mathrm{mV}$. Inclusion in the patch pipette of the peptide Pep-A2 $(100 \mu \mathrm{g} / \mathrm{mL})$ prevented LTP (B, D. $p=0.01$ vs. control; $p=0.018$ vs. Pep-Scramble). In contrast, inclusion of a scrambled form of peptide Pep-Scramble $(100 \mu \mathrm{g} / \mathrm{mL})$ and the Pep-A3 $(100 \mu \mathrm{g} / \mathrm{mL})$ had little effect on LTP (A, C, D). The conditioning EPSC (vs. baseline $30 \mathrm{~min}$ after stimulation) of different groups was shown in D. In all graphs, the amplitude of individual EPSCs was normalized to the mean value of amplitudes of all EPSCs during the 10-min baseline recordings before the induction of LTP.
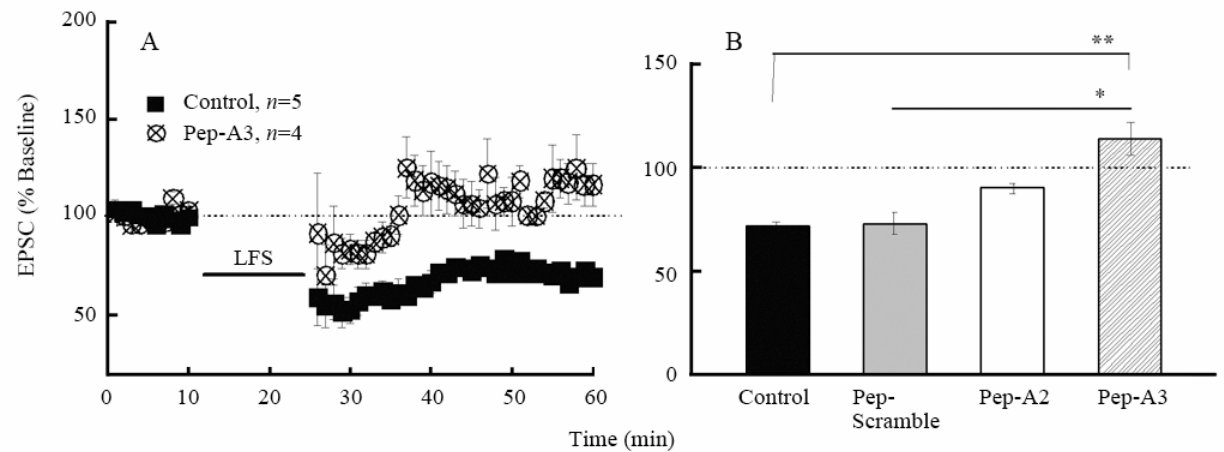

Fig. 2 Blockade of hippocampal LTD by Pep-A3 in mice

LTD was prevented (A, B. $p=0.003$ vs. control; $p=0.02$ vs. Pep-scramble) while inclusion of the peptide Pep-A3, $(100 \mu \mathrm{g} / \mathrm{mL})$, which was induced by pairing presynaptic stimulation $(1 \mathrm{~Hz})$ with postsynaptic depolarization by holding membrane potential at $-50 \mathrm{mV}$. Whereas inclusion of the scrambled form of peptide Pep-Scramble $(100 \mu \mathrm{g} / \mathrm{mL})$ and the Pep-A2 $(100 \mu \mathrm{g} / \mathrm{mL})$ had little effect on LTD (B, data not shown because of limited numbers). The conditioning EPSC (vs. baseline $30 \mathrm{~min}$ after stimulation) of different groups was shown in B. In all graphs, the amplitude of individual EPSCs was normalized to the mean value of amplitudes of all EPSCs during the 10-min baseline recordings before the induction of LTD. 

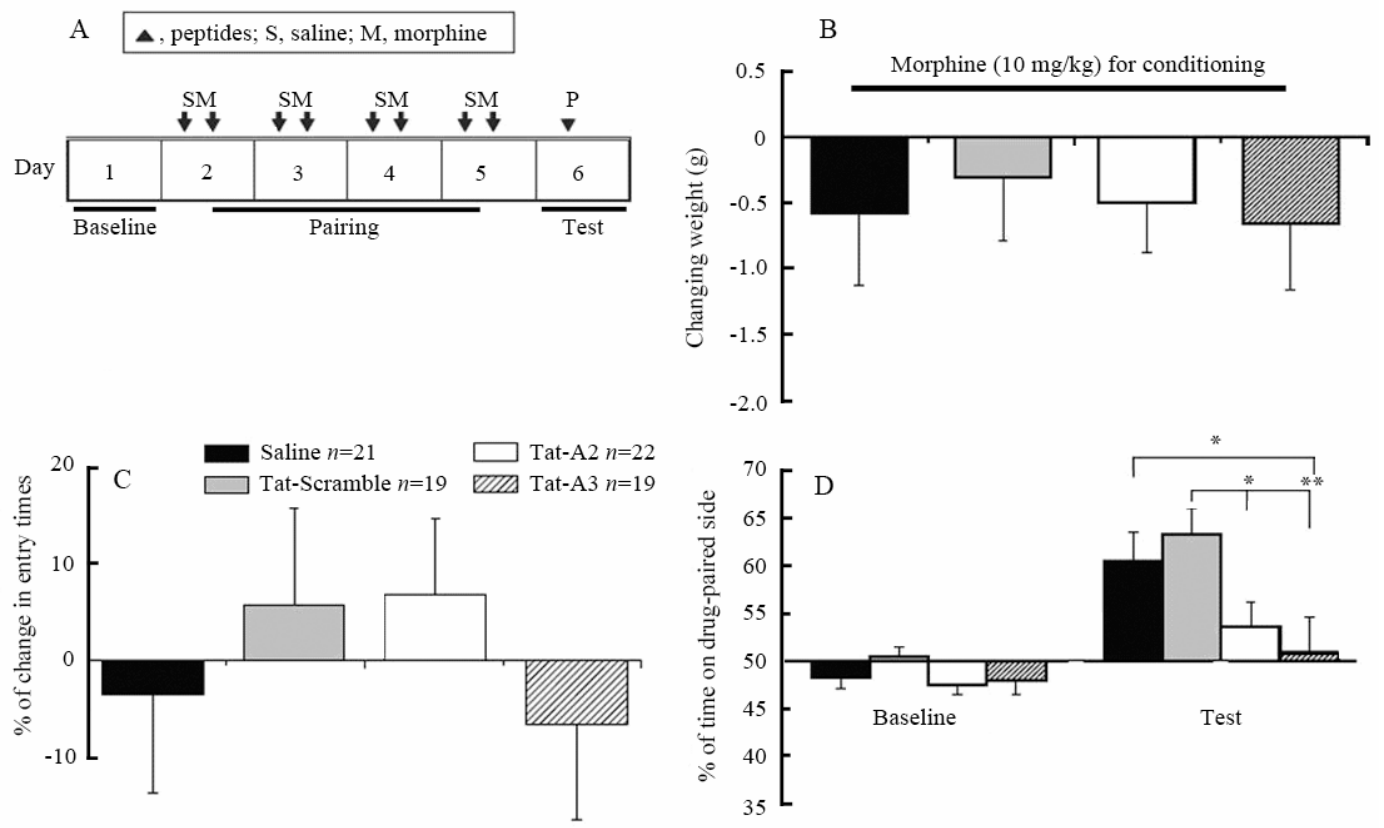

Fig. 3 The absent of LTP/LTD impaired the expression of Morphine CPP

A: Schematic illustrating the design of the CPP paradigm. B: Changing weight measured on day 1 and day 6 after test. C: Exploratory activity as measured by the changes of chamber entries. D: CPP for $10 \mathrm{mg} / \mathrm{kg}$ (i.p.) morphine. Mice with the pretreatment of Pep-A2, or Pep-A3 showed impired expression of CPP (Pep-A2 vs. Saline, $p=0.081$; Pep-A2 vs. Pep-Scramble, $p=0.017$; Pep-A3 vs. Saline, $p=0.019$; Pep-A2 vs. Pep-Scramble, $p=0.003)$. Scores are presented as the percentage of time spent in the drug-paired side compared to the saline-paired side during the baseline and testing phase, Animals received peptides $(1.5 \mathrm{nmol} / \mathrm{L} / \mathrm{g}$, i.v.) $90 \mathrm{~min}$ before the beginning of the test in the 6th day of experiments.

LTD appears to be necessary for the expression of Morphine CPP.

\section{Discussion}

CPP is an animal model widely used to measure the rewarding properties of addictive drugs as reflected by the rewarding reinforced association of context and drugs of abuse (Dong et al, 2006). Our present findings demonstrate the individual role of LTP or LTD in addiction for the first time, that is, either LTP or LTD is the necessary requirement for the expression of Morphine CPP.

Traditionally, dopamine has received most attention as the key player in drug addiction (Wise, 2004; Schultz, 2004; Phillips et al, 2003). However, the bulk of studies support a role for glutamate in learning and other adaptive processes in animal models of drug addiction (Kauer, 2004; Kelley, 2003; Wolf, 1998; Jackson et al, 2000). Moreover, it has become clear that LTP and its counterpart, LTD, are basic properties of most excitatory glutamatergic synapses throughout the central neural system (CNS), and are used for multiple brain functions in addition to learning and memory (Malenka \& Bear, 2004). For example, NMDA receptor blockade, known to prevent many forms of LTP and LTD in other brain regions (Malenka \& Bear, 2004), also prevents Morphine CPP (Harris, 2004; Tzschentke, 1995), but which could not discriminate the exact role of LTP and LTD. In addtion, NMDA receptor blockade does not prevent the acute locomotor response to psychostimulant drugs, which is in accordance with our results.

The dopaminergic and glutamatergic systems, particularly through dopamine D-1 and glutamate NMDA and AMPA receptors, shared similar neural circuitry and molecular mechanisms (Kelley, 2004). Axons containing dopamine and glutamate converge onto dendritic spines within striatal and other corticolimbic regions. This convergence leads to activation of intracellular transduction mechanisms, induction of regulatory transcription factors, and long-term changes in cellular plasticity involving a myriad of postsynaptic density proteins (Kelley, 2004; Berke \& Hyman, 2000). Extracellular signal-regulated kinase (ERK) plays an important role in the underlying molecular mechanisms of this process. In striatal 
medium-sized spiny neurons (MSNs), ERK2 activation requires the concomitant stimulation of dopamine D1 receptors and glutamate NMDA receptors, and possibly other receptors including mGluR5. Thus, the ERK2 pathway operates as a logical AND gate (Girault, 2007), which detects the coincident activation of glutamate inputs, presumably encoding contextual information related to environmental cues and internal state, and dopamine inputs that encode the reward prediction error signal (Schultz, 2006). In other systems, the ERK2 pathway is a molecular switch, transforming graded inputs into 'all-or-none' responses (Ferrell, 2002). It could function similarly as in striatal neurons, that is when a certain level of activation is achieved, as a combined function of dopamine and glutamate inputs, the threshold for ERK2 activation is reached and the neuron switches into a plasticity permissive state that favors the establishment of long-lasting changes. Therefore, we hypothesis that the expression of CPP or other (conditioned behavioral response) is mainly dependent on the overall effect of MSNs in ventral striatum. Systematically treatment of Tat-A2 may

\section{Reference:}

Beninger RJ, Hahn BL. 1983. Pimozide blocks establishment but not expression of amphetamine-produced environment-specific conditioning[J]. Science, 220: 304-1306.

Berhow MT, Hiroi N, Nestler EJ. 1996. Regulation of ERK (extracellular signal regulated kinase), part of the neurotrophin signal transduction cascade, in the rat mesolimbic dopamine system by chronic exposure to morphine or cocaine[J]. J Neurosci, 16(15): 4707-4715.

Berke JD, Hyman SE. 2000. Addiction, dopamine, and the molecular mechanisms of memory[J]. Neuron, 25(3): 515-532.

Brebner K, Wong TP, Liu LD, Liu YT, Campsall P, Gray S, Phelps L, Phillips AG, Wang YT. 2005. Nucleus accumbens long-term depression and the expression of behavioral sensitization[J]. Science, 310(5752): 1340-1343.

Dong ZF, Han HL, Wang MN, Xu L, Hao W, Cao J. 2006. Morphine conditioned place preference depends on glucocorticoid receptors in both hippocampus and nucleus accumbens[J]. Hippocampus, 16(10): 809-813.

Ferrell JE Jr. 2002. Self-perpetuating states in signal transduction: positive feedback, double-negative feedback and bistability[J]. Curr Opin Cell Biol, 14(2): 140-148.

Ge WP, Yang XJ, Zhang ZJ, Wang HK, Shen WH, Deng QD, Duan SM. 2006. Long-term potentiation of neuron-glia synapses mediated by $\mathrm{Ca}^{2+}$-permeable AMPA receptors[J]. Science, 312(5779): 1533-1537.

Girault JA, Valjent E, Caboche J, Hervé D. 2007. ERK2: a logical AND gate critical for drug-induced plasticity?[J]. Curr Opin Pharmacol, 7(1): 77-85.

Goldin M, Segal M. 2003. Protein kinase C and ERK involvement in dendritic spine plasticity in cultured rodent hippocampal interfere with LTP formed in ventral tegmental area, which is of vital importance in reward circuits during morphine administration (Berhow, 1996), whereas Tat-A3 may interfere with LTD formed in hippocampus, which disrupts the reward and context input respectively.

In addition, the dissociation of mechanisms underlying acquisition and expression of drug effects on behaviour is evident in a wide variety of pharmacological studies (Robertson et al, 1982; Beninger \& Hahn 1983; Hand \& Franklin 1986; Snodgrass \& Allen 1988), and presumably the expression of morphine reward attributes to unidentified mechanisms rather than the traditional reward circuit.

In summary, our results confirmed the importance of glutamatergic system in the reward related learning and memory, and suggest the both necessary role of LTP and LTD in the expression of Morphine CPP.

Acknowledgments: We greatly thank ZHAO Xiao-ying for behavioral studies, MAO Rong-rong, and WEN Fei for reading the manuscript.

neurons[J]. Eur J Neurosci, 17(12): 2529-2539.

Hand TH, Franklin KBJ. 1986. Associative factors in the effects of morphine on self-stimulation[J]. Psychopharmacology, 88: 472-479.

Hand TH, Stinus L, Le Moal M. 1989. Differential mechanisms in the acquisition and expression of heroin-induced place preference[J]. Psychopharmacology (Berl), 98(1): 61-67.

Harris GC, Wimmer M, Byrne R, Aston-Jones G. 2004. Glutamate-associated plasticity in the ventral tegmental area is necessary for conditioning environmental stimuli with morphine[J]. Neuroscience, 129(3): 841-847.

Hnasko TS, Sotak BN, Palmiter RD. 2005. Morphine reward in dopamine-deficient mice[J]. Nature, 438(7069): 854-857.

Hsu EH, Schroeder JP, Packard MG. 2002. The amygdala mediates memory consolidation for an amphetamine conditioned place preference[J]. Behav Brain Res, 129(1-2): 93-100.

Hyman SE, Malenka RC, Nestler EJ. 2006. Neural mechanisms of addiction: the role of reward-related learning and memory $[\mathrm{J}]$. Annu Rev Neurosci, 29: 565-598.

Jackson A, Mead AN, Stephens DN. 2000. Behavioural effects of alpha-amino-3-hydroxy-5-methyl-4-isoxazolepropionate-receptor antagonists and their relevance to substance abuse[J]. Pharmacol Ther, 88(1): 59-76.

Jones S, Bonci A. 2005. Synaptic plasticity and drug addiction[J]. Curr Opin Pharmacol, 5(1): 20-25.

Kauer JA. 2004. Learning mechanisms in addiction: synaptic plasticity in the ventral tegmental area as a result of exposure to drugs of abuse[J]. Annu Rev Physiol, 66: 447-475.

Kelley AE. 2004. Memory and addiction: shared neural circuitry and molecular mechanisms[J]. Neuron, 44(1): 161-179. 
Kelley AE, Andrzejewski ME, Baldwin AE, Hernandez PJ, Pratt WE. 2003. Glutamate-mediated plasticity in corticostriatal networks: Role in adaptive motor learning[J]. Ann NY Acad Sci, 1003: 159-168.

Li HB, Zhang JH, Xiong WY, Xu TL, Cao J, Xu L. 2005. Long-term depression in rat CA1-subicular synapses depends on the G-protein coupled mACh receptors[J]. Neurosci Res, 52(3): 287-294.

Li HB, Han HL, Ma WP, Dong ZF, Xu L. 2007. Enhancement of $\mathrm{GABA}_{\mathrm{A}}$ receptor-mediated inhibitory postsynaptic currents induced by “partial oxygen-glucose deprivation” [J]. Zool Res, 28(5): 491-496.

Malenka RC. 2003. Synaptic plasticity and AMPA receptor trafficking[J]. Ann N Y Acad Sci, 1003: 1-11.

Malenka RC, Bear MF. 2004. LTP and LTD: An embarrassment of riches[J]. Neuron, 44(1): 5-21.

Malinow R, Malenka RC. 2002. AMPA receptor trafficking and synaptic plasticity[J]. Annu Rev Neurosci, 25: 103-126.

Phillips PE, Stuber GD, Heien ML, Wightman RM, Carelli RM. 2003. Subsecond dopamine release promotes cocaine seeking[J]. Nature, 422(6932): 614-618.

Radwanska K, Caboche J, Kaczmarek L. 2005. Extracellular signal-regulated kinases (ERKs) modulate cocaine-induced gene expression in the mouse amygdala[J]. Eur J Neurosci, 22(4): 939-948.

Robertson A, Laferri+re A, Milner PM. 1982. Treatment with anticonvulsant drugs retards the development of brain-stimulation reward in the prefrontal cortex[J]. Physiol Behav, 29: 275-280.

Schultz W. 2004. Neural coding of basic reward terms of animal learning theory, game theory, microeconomics and behavioural ecology[J]. Curr Opin Neurobiol, 14(2): 139-147.

Schultz W. 2006. Behavioral theories and the neurophysiology of reward[J]. Annu Rev Psychol, 57: 87-115.

Snodgrass SH, Allen JD. 1988. The effects of apomorphine on the acquisition of schedule-induced polydipsia in rats[J]. Pharmacol Biochem Behav, 29: 483-488.

Sweatt JD. 2004. Mitogen-activated protein kinases in synaptic plasticity and memory[J]. Curr Opin Neurobiol, 14(3): 311-317.

Terashima A, Pelkey KA, Rah JC, Suh YH, Roche KW, Collingridge GL, McBain CJ, Isaac JT. 2008. An essential role for PICK1 in NMDA receptor-dependent bidirectional synaptic plasticity[J]. Neuron, 57(6): 872-882.

Tzschentke TM. 1998. Measuring reward with the conditioned place preference paradigm: a comprehensive review of drug effects, recent progress and new issues[J]. Prog Neurobiol, 56(6): 613-672.

Tzschentke TM, Schmidt WJ. 1995. N-methyl-D-aspartic acid-receptor antagonists block morphine-induced conditioned place preference in rats[J]. Neurosci Lett, 193(1): 37-40.

White NM, Carr GD. 1985. The conditioned place preference is affected by two independent reinforcement processes $[\mathrm{J}]$. Pharmacol Biochem Behav, 23(1): 37-42.

Wise RA. 2004. Dopamine, learning and motivation[J]. Nat Rev Neurosci, 5(6): 483-494.

Wolf ME. 1998. The role of excitatory amino acids in behavioral sensitization to psychomotor stimulants[J]. Prog Neurobiol, 54(6): 679-720.

Wu GY, Deisseroth K, Tsien RW. 2001. Spaced stimuli stabilize MAPK pathway activation and its effects on dendritic morphology[J]. Nat Neurosci, 4(2): 151-158.

Wu JQ, Wang Y, Rowan MJ, Anwyl R. 1998. Evidence for involvement of the cGMP-protein kinase G signaling system in the induction of long-term depression, but not long-term potentiation, in the dentate gyrus in vitro[J]. J Neurosci, 18(10): 3589-3596.

Zhu JJ, Qin Y, Zhao MM, Van Aelst L, Malinow R. 2002. Ras and Rap control AMPA receptor trafficking during synaptic plasticity[J]. Cell, 110(4): 443-455. 